\title{
Allometric Equations for Estimating Aboveground Biomass of Eucalyptus urophylla S.T. Blake in East Nusa Tenggara
}

\author{
Ronggo Sadono ${ }^{1}$, Wahyu Wardhana ${ }^{1}$, Pandu Yudha Adi Putra Wirabuana ${ }^{1 *}$, Fahmi Idris ${ }^{2}$ \\ ${ }^{1}$ Department of Forest Management, Faculty of Forestry, Universitas Gadjah Mada, \\ Jl. Agro No. 1 Bulaksumur, Yogyakarta, Indonesia 55281 \\ ${ }^{2}$ Department of Research and Development, TROFSIT Institute, \\ Jl. Kaliurang Km 16, Yogyakarta, Indonesia 55281
}

Received August 25, 2020/Accepted March 2, 2021

\begin{abstract}
Understanding the essential contribution of eucalyptus plantation for industry development and climate change mitigation requires the accurate quantification of aboveground biomass at the individual tree species level. However, the direct measurement of aboveground biomass by destructive method is high cost and time consuming. Therefore, developing allometric equations is necessary to facilitate this effort. This study was designed to construct the specific allometric models for estimating aboveground biomass of Eucalyptus urophylla in East Nusa Tenggara. Forty two sample trees were utilized to develop allometric equations using regression analysis. Several parameters were selected as predictor variables, i.e. diameter at breast height $(D)$, quadrat diameter at breast height combined with tree height $\left(D^{2} H\right)$, as well as $D$ and H separately. Results showed that the mean aboveground biomass of E. urophylla was $143.9 \pm 19.44 \mathrm{~kg}$ tree $e^{-1}$. The highest biomass were noted in stem (80.06\%), followed by bark (11.89\%), branch $(4.69 \%)$, and foliage $(3.36 \%)$. The relative contribution of stem to total aboveground biomass improved with the increasing of diameter class while the opposite trend was recorded in bark, branch, and foliage. The equation $\ln \hat{Y}$ $=\ln a+b \ln D$ was best and reliable for estimating the aboveground biomass of E. urophylla since it provided the highest accurate estimation (91.3\%) and more practical than other models. Referring to these findings, this study concluded the use of allometric equation was reliable to support more efficient forest mensuration in E. urophylla plantation.
\end{abstract}

Keywords: forest mensuration, accurate quantification, eucalyptus, industry development, climate change

*Correspondence author, email:pandu.yudha.a.p@ugm.ac.id, tel.+62-274-548815,fax.+62-274-54881

\section{Introduction}

Integration of industry development and climate change mitigation currently become the most priority issue of eucalyptus plantation management, particularly in tropical countries such as Indonesia, Vietnam, and Brazil (Wirabuana et al., 2019). In this context, the existence of eucalyptus plantation is not only expected to stabilize timber supply for industry but also to reduce greenhouse gas emissions in the atmosphere (Sanquetta et al., 2018). However, the meaningful contribution of eucalyptus plantation for those objectives generally varies in each site depending on its biomass production. Many literatures confirm higher biomass accumulation indicates greater contribution of plantation forest in maintaining industry viability and reducing carbon emissions (Pirralho et al., 2014; Nunes et al., 2019; Wirabuana et al., 2020). It signifies the availability information about biomass is importantly required to understand the important contribution of eucalyptus plantation for industry sustainability and climate change alleviation

The accurate quantification of forest attributes, mainly related to biomass are basically determined by the precise measurement at the individual tree level (Altanzagas et al., 2019). The higher precision of the individual tree measurement will generate better accuracy in calculating stand attributes (St-Onge \& Grandin, 2019). Thus, the activity of forest mensuration using destructive method is commonly conducted to obtain more accurate data from individual trees (Goussanou et al., 2016). Nevertheless, the implementation of forest inventory using destructive approach requires high cost and is time consuming (Wardhana et al., 2020). This method is also not relevant to conduct in compartments which dominated by young trees since it has a potential to decline the regeneration capacity (Duncanson et al., 2015). In contrast, the information are necessary to forest managers as the basis of planning determination, especially regarding to yield regulation. The data of forest biomass are also helpful to compute the 
capacity of forest for carbon absorption that frequently used as one of the indicators in forest certification. Therefore, developing allometric equations is necessary to facilitate the estimation of timber production, biomass accumulation, and carbon storage in eucalyptus plantation.

Some references have evidenced the use of allometric equation is reliable to conduct the accurate estimation of individual tree parameters (Nugroho, 2014; Manuri et al., 2016; Zhao et al., 2019). For example, in Brazilian plantation forests, the use of allometric equations provides a good accuracy to estimate aboveground biomass of $E$. grandis (Ribeiro et al., 2015). The similar outcomes are also reported from Spain, in which the utilization of allometric models is helpful to obtain the accurate quantification of above and belowground biomass in E. globulus (Vega-Nieva et al., 2015). Moreover, the reliability of allometric models for estimating biomass in every component and total of eucalyptus tree has been also reported in Indonesia. For example, a study from commercial eucalyptus plantation in South Sumatra reveals that the usage of allometric equations provides an accuracy more than $70 \%$ for quantifying aboveground biomass in every component of E. pellita (Inail et al., 2019). Another study conducted in natural forest in East Nusa Tenggara also reports the accuracy of biomass estimation in E. urophylla using allometric models reached $86.3 \%$ (Almulqu et al., 2019). These explanations verify that the development of allometric equations has a potential to contribution to facilitating more efficient forest mensuration, primarily in eucalyptus plantation.

Several studies explain the accuracy of allometric models as a proxy approach to estimate individual tree parameters has certain limitations since those equations are developed based on the growth performance of tree species in the surveyed area (Forrester et al., 2017; Altanzagas et al., 2019; Daba \& Soromessa, 2019). In this context, the different plant species, site condition, type of forest, and silviculture treatment will influence the reliability of allometric models for resulting the accurate estimation (Roxburgh et al., 2015). A study from Khangai, Mongolia, have evidenced the different species will generate a specific form of allometric models in which each equation has diverse accuracy in predicting biomass from various species (Altanzagas et al., 2019). Another study from community forests in Madiun also records the adoption of allometric equations from other location provides lower accuracy for estimating total individual tree biomass than the best models generated in study site (Wirabuana et al., 2020). These examples confirm that there are some limitations to apply allometric equations for estimating tree biomass.

This study aims to develop allometric equations for estimating aboveground biomass of E. urophylla that managed by KPH Timor Tengah Selatan. It was designed to support more efficient forest mensuration in the context of industry development and climate change mitigation. Compared to the previous studies related to the development of allometric models for predicting E. urophylla biomass in East Nusa Tenggara (Marimpan, 2010; Almulqu et al., 2019), our study has several different aspects. First, this study was carried out in plantation forest with monoculture species while both previous studies were undertaken in natural forest with mixed plant species. Second, the stand attributes of $E$. urophylla in this study was relatively homogenous reviewed from age of stand, spacing, and silviculture regime while the previous studies had heterogenous stand condition. Third, this study used more number of tree samples for developing allometric equations than both previous studies. At the end, the specific objectives of our study are 1) to quantify aboveground biomass in every component and total of $E$. urophylla, 2) to assess the relative contribution of every tree component to total aboveground biomass of E. urophylla, and 3 ) to formulate the best allometric models for estimating total aboveground biomass of E. urophylla.

\section{Methods}

Study area This study was conducted in E. urophylla plantation, managed by KPH Timor Tengah Selatan. It is situated in Timor Tengah Selatan District, approximately 180 $\mathrm{km}$ at the Northeastern Kupang, the capital city of East Nusa Tenggara Provinces. The study site has a geographic position in $\mathrm{S}^{\circ} 50^{\prime} 0^{\prime \prime}$ to $\mathrm{S} 9^{\circ} 50^{\prime} 15^{\prime \prime}$ and $\mathrm{E} 124^{\circ} 15^{\prime} 30^{\prime \prime}$ to $\mathrm{E} 124^{\circ} 16^{\prime} 0^{\prime \prime}$ (Figure 1). It has total area of E. urophylla plantation around 250 ha which is distributed in 2 different villages, i.e. Buat and Fatukoto. However, the area of E. urophylla plantation is divided into 3 compartments referring to the planting time, i.e. Buat 1982 (75 ha), Fatukoto 1983 (100 ha), and Fatukoto 1997 (25 ha). In every site, the initial planting density is relatively equal $\left(1,333\right.$ tree $\left.\mathrm{ha}^{-1}\right)$ even though there is a different planting periods. The treatment of fertilization, thinning, and prunning were never conducted in each area since at the beginning those compartments were managed as protected forest.

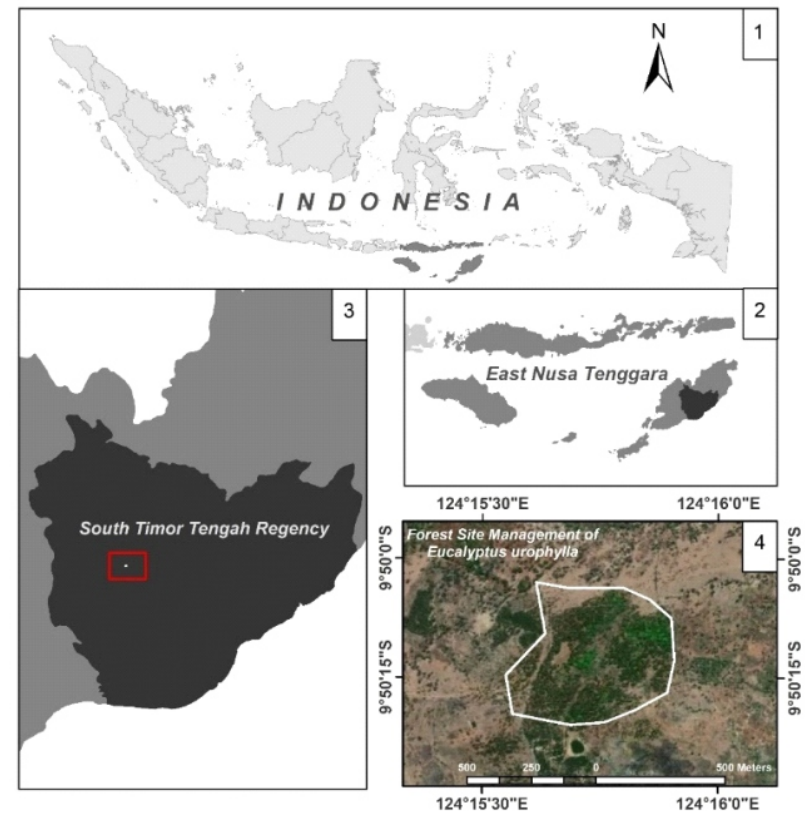

Figure 1 The study site of E. urophylla plantation managed by KPH Timor Tengah Selatan. The white polygon demonstrated the primary compartments of $E$. urophylla plantation which designed as a commercial plantation forest. 
Altitude varies from 800 to $1,000 \mathrm{~m}$ above sea level. Topography is relatively gradient with slope level ranging from 15 to $45 \%$. Soil type is dominated by cambisol which has high phosphorus content and great cation exchange capacity (Table 1). This area is classified into humid condition with the mean air humidity around $85.5 \%$. The average daily temperature is $29^{\circ} \mathrm{C}$ with a minimum of $23{ }^{\circ} \mathrm{C}$ and a maximum of $30^{\circ} \mathrm{C}$. The annual rainfall varied from 1,500 to $3,000 \mathrm{~mm}$ year ${ }^{-1}$ during the past ten years from 2010 to 2019. Most rainfall occurrs from November to January with the highest rainfall is recorded in January. Dry periods is noted for 7 months from March to September (Kalima et al., 2019).

At the preliminary periods, before converted into $E$. urophylla plantation, the study location was a bare land without trees vegetation. The land cover was predominantly by Imperata cylindrica. Starting from 1980s, the local government implemented forest and land rehabilitation program by selecting $E$. urophylla as the primary species for reforestation. Besides having rapid growth, E. urophylla is also a native species from this site. This effort was continously conducted until the late of 2016 without having an economic objectives. However, since 2017, after initiating the development of KPH Timor Tengah Selatan and considering the economic values of E. urophylla, the aims of management has been transformed into commercial plantation forest for encouraging the effort of economic development in rural area (Sadono et al., 2020).

Data collection 42 sample trees were selected for destructive sampling. The sample trees were determined by considering the diameter distribution to derive the balance growth dimension from small to big trees (Guendehou et al., 2012). In this study, we classified trees diameter into five different classes, i.e. $6-10 \mathrm{~cm}, 11-15 \mathrm{~cm}, 16-20 \mathrm{~cm}, 21-25 \mathrm{~cm}$, and 26-30 cm (Altanzagas et al., 2019). The process of destructive sampling was conducted step by step in chronological manner. After the selected trees were cut down, their tree components were separated into stem, bark, branch, and foliage. The stem and bark were split since our study aimed to obtain more detail information about biomass in every tree component. However, before both component was separated, the wood volume of every tree was calculated by Smallian method as shown in Equation [1].

$$
V=\frac{\pi}{8}\left(D_{L}^{2}+D_{S}^{2}\right) L
$$

note: $V$ was stem volume, $D_{L}$ represented size of stem diameter at the large end, $D_{s}$ indicated size of stem diameter at the small end, and $L$ was the length of stem.

The fresh weight of every part was quantified using a hanging balance in the field. Then, $500 \mathrm{~g}$ sub-sample from each part was taken to the laboratory for drying (Wirabuana et al., 2019). The drying process was done using an oven at $70{ }^{\circ} \mathrm{C}$ for 48 hours before weighting for biomass calculation (Hakamada et al., 2017). Total biomass accumulation in every component of sample trees was determined by multiplying the ratio of dry-fresh weight from sub-sample with the total fresh-weight of each part which recorded from the field survey (Altanzagas et al., 2019). The outcomes of biomass calculation were used to count carbon storage within each component since almost $50 \%$ of biomass was composed by carbon element (Viera \& Rodríguez-Soalleiro, 2019).

Data analysis Statistical analysis was carried out using $\mathrm{R}$ software version 4.0 .2 with a significant level of $5 \%$ (R Core Team, 2017). The easyreg package was selected to support data analysis (Arnhold, 2018). Descriptive test was undertaken to identify several data attributes, i.e. minimum, maximum, mean, standard deviation, and standard error (Mishra et al., 2019). It was intended to demonstrate the results of destructive sampling for each observation parameters. The data normality was examined using ShapiroWilk test (Ghasemi \& Zahediasl, 2012).

Data were divided into two groups to construct allometric models. The first group was used to develop equations (30 sample trees) while the second group was utilize to validate models (12 trees). In this study, three general allometric models were evaluated for predicting total aboveground biomass of E. urophylla. Several independent variables were selected to formulate equations, namely diameter at breast height $(D)$, squared diameter at breast height combined with tree height $\left(D^{2} H\right)$, as well as $D$ and $H$ separately (Xue et al., 2016; Altanzagas et al., 2019; Wirabuana et al., 2020). The measurement unit of $D$ and $H$ for each was $\mathrm{cm}$ and $\mathrm{m}$. Both parameters were measured before tree felled. The measurement of $D$ was conducted at $1.3 \mathrm{~m}$ from aboveground using diameter tape while the measurement of $H$ was undertaken from aboveground to top crown using hagameter. Details of allometric equations were expressed in Equation [2], Equation [3], and Equation [4].

$$
\hat{Y}=a D^{b}
$$

Table 1 Soil chemical properties in the study site referring to the results of laboratory analysis for soil $\mathrm{pH}$, soil organic carbon $(\mathrm{SOC})$, total nitrogen $(\mathrm{N})$, available phosphorus $(\mathrm{P})$, total potassium $(\mathrm{K})$, and cation exchange capacity $(\mathrm{CEC})$

\begin{tabular}{lcccc}
\hline \multirow{2}{*}{ Parameter } & \multirow{2}{*}{ Unit } & \multicolumn{3}{c}{ Estates } \\
\cline { 3 - 5 } & & Buat 1982 & Fatukoto 1983 & Fatukoto 1997 \\
\hline $\mathrm{pH}$ & - & 5.10 & 4.32 & 6.50 \\
$\mathrm{SOC}$ & $\%$ & 1.96 & 1.02 & 0.62 \\
$\mathrm{~N}$ & $\%$ & 0.36 & 0.22 & 0.39 \\
$\mathrm{P}$ & $\mathrm{ppm}$ & 40.83 & 29.12 & 41.60 \\
$\mathrm{~K}$ & 1.10 & 0.51 & 0.59 \\
$\mathrm{CEC}$ & cmolc kg $^{-1}$ & 34.90 & 33.12 & 34.56 \\
\hline
\end{tabular}

Source: Kurniadi \& Pujiono (2009) 


$$
\begin{aligned}
& \hat{Y}=a\left(D^{2} H\right)^{b} \\
& \hat{Y}=a D^{b} H^{c}
\end{aligned}
$$

note: $\hat{Y}$ was the estimated parameters and $\mathrm{a}, \mathrm{b}$, and $\mathrm{c}$ were the fitted parameters.

In general, the use of nonlinear tree growth models based on arithmetic units did not have constant error variance values over all observations in most cases (Altanzagas et al., 2019). It was commonly referred to as heteroscedasticity. To eliminate the influence of heteroscedasticity, the use of data transformation in natural log-form was conducted on a regular basis to change the nonlinear model into linear regression when quantifying parameters for equations (He et al., 2018). Therefore, Equation [2], Equation [3], and Equation [4] were converted into the models as shown in Equation [5], Equation [6], and Equation [7].

$$
\begin{aligned}
& \ln \hat{Y}=\ln a+b \times \ln D \\
& \ln \hat{Y}=\ln a+b \times \ln \left(D^{2} H\right) \\
& \ln \hat{Y}=\ln a+b \times \ln D+c \times \ln H
\end{aligned}
$$

note: $\ln \hat{Y}$ was the estimated values in the logarithmic unit and $a, b, c$, were the fitted parameters. The previous studies have been reported the similart method (log-transformed linear regression) for modeling tree characteristics (He et al., 2018; Altanzagas et al., 2019; Wirabuana et al., 2020). The antilog transformation of the estimated logarithmic values into arithmetic units leads to a systematic bias which could generally be corrected by the correction factor as shown in Equation [8] (Altanzagas et al., 2019).

$$
C F=\exp \left(\frac{R M S E^{2}}{2}\right)
$$

note: $C F$ was the correction factor and $R M S E$ was the root mean square error from the logarithmic regression, and $n$ was the sample size.

Six indicators were selected to evaluate the best allometric models, i.e. the significant of fitted parameters (a, b, c) had to be significant, adjusted coefficient of determination $\left(R^{2}{ }_{a d j}\right)$, residual standard error $(R S E)$, root mean square error (RMSE), mean absolute bias $(M A B)$, akaike information criterion (AIC) (González-García et al., 2013; Ekoungoulou et al., 2015; Altanzagas et al., 2019). The indicator $R_{a d j}^{2}$ and $R S E$ were used to evaluate the stage of model fitting while RMSE, MAB, and AIC were applied to examine the validation stage. The details formula for computing those statistical parameters were expressed in Equation [9], Equation [10], Equation [11], Equation [12], and Equation [13].

$$
\begin{aligned}
& R^{2}{ }_{a d j}=1-\left[\frac{\left(1-R^{2}\right)(n-1)}{n-k-1}\right] \\
& R S E=\sqrt{\frac{1}{n-2} \sum(\ln Y-\ln \hat{Y})^{2}} \\
& R M S E=\sqrt{\sum(\ln Y-\ln \hat{Y})^{2} /(n-p-1)} \\
& M A B=\sum(|\ln Y-\ln \hat{Y}|) / n \\
& A I C=n \log \left(\frac{R S S}{n}\right)+2 k+\frac{2 k+(k+1)}{n-k-1}
\end{aligned}
$$

note: $\ln$ indicated the actual $\log$-transformed parameters, $\ln Y$ was the estimated log-transformed parameters from the fitted model, $n$ was the sample size, $\ln Y$ was the mean actual logtransformed parameters, $R^{2}$ was coefficient determination, $p$ was the number of terms in the model, $R S S$ was the residual sum of squares from the fitted model, and $k$ was the number of parameters. Furthermore, we also compared our best models with another allometric equations of E. urophylla from different locations in East Nusa Tenggara which are published by Almulqu et al. (2019). The previous research was implemented in natural forests of E. urophylla in Mutis Timau.

\section{Results and Discussion}

Stand characteristics Summarized results of the observation showed the average stem volume of E. urophylla in the surveyed area was $0.23 \pm 0.03 \mathrm{~m}^{3}$ tree ${ }^{-1}$ with a mean diameter of $16.0 \pm 0.9 \mathrm{~cm}$ and height of $23.8 \pm 1.0 \mathrm{~m}$ (Table 2). The highest mean biomass was noted in stem $(118.76 \pm 16.91 \mathrm{~kg})$, followed by bark $(13.02 \pm 1.26 \mathrm{~kg})$, branch $(2.37 \pm 0.79 \mathrm{~kg})$, and foliage $(2.77 \pm 0.51 \mathrm{~kg})$. The similar pattern was also observed in the distribution of carbon storage in every tree component (Table 3 ). This trend was frequently found since carbon was the main component of biomass (Viera \& Rodríguez-Soalleiro, 2019). This study also realized more than $70 \%$ of total aboveground biomass were accumulated in stem (Table 4). It was consistently similar to other previous studies which reported from eucalyptus plantation at different forest regions (Ribeiro et al., 2015; Vega-Nieva et al., 2015; Tesfaye et al., 2020). The distribution of biomass in stem was considerably higher than other components because it is the main tree component in supporting translocation process and maintaining tree stability.

This study observed the allocation of total aboveground biomass into tree components along diameter class indicated that stem had the greatest accumulation approximately $70-82 \%$ (Table 4). Interestingly, the trend of biomass distribution in every part was relatively different across the increasing diameter classes. The relative contribution of bark and foliage biomass slightly declined from the smallestdiameter class to the largest one. In contrast, the biomass allocation in stem and branch improved with the increasing diameter classess. These findings verified there was a strong relationship between the dimension size of tree diameter with the process of biomass distribution. It was equal to the previous studies which focused on biomass distribution within trees (He et al., 2018; Altanzagas et al., 2019; Wirabuana et al., 2020). The percentage of branch and foliage biomass declined with the increment of tree diameter indicated that relatively more biomass was allocated to the trunk (stem + bark) for improving the growth and accelerating the translocation process (Wirabuana et al., 2020).

Allometric equations for estimating aboveground biomass The results clearly presented that every allometric equations had good fit $(p<0.05)$ (Table 5). Surprisingly, the best allometric equations for estimating total aboveground 
Tabel 2 Minimum (min), maximum (max), average (mean), standard deviation (SD), and standard error (SE) of wood volume, aboveground biomass, and carbon storage in Eucalyptus urophylla at the sampling location

\begin{tabular}{|c|c|c|c|c|c|c|}
\hline Parameter & Unit & Min & Max & Mean & SD & SE \\
\hline \multicolumn{7}{|c|}{ Individual tree dimension } \\
\hline Diameter & $\mathrm{cm}$ & 6.8 & 25.9 & 16.0 & 4.7 & 0.9 \\
\hline Height & $\mathrm{m}$ & 13.4 & 34.4 & 23.8 & 5.3 & 1.0 \\
\hline Vol ume & $\mathrm{m}^{3}$ tree $^{-1}$ & 0.02 & 0.72 & 0.23 & 0.17 & 0.03 \\
\hline \multicolumn{7}{|c|}{ Aboveground biomass allocation } \\
\hline Stem & $\mathrm{kg}$ tree $^{-1}$ & 12.68 & 411.94 & 118.76 & 92.65 & 16.91 \\
\hline Bark & $\mathrm{kg} \operatorname{tree}^{-1}$ & 1.28 & 31.16 & 13.02 & 6.90 & 1.26 \\
\hline Branch & $\mathrm{kg}$ tree $^{-1}$ & 0.53 & 78.62 & 7.88 & 14.43 & 2.63 \\
\hline Foliage & $\mathrm{kg}_{\text {tree }}{ }^{-1}$ & 0.45 & 11.19 & 4.23 & 2.77 & 0.51 \\
\hline Total & $\mathrm{kg}$ tree $^{-1}$ & 14.93 & 430.73 & 143.90 & 106.50 & 19.44 \\
\hline \multicolumn{7}{|c|}{ Carbon storage distribution } \\
\hline Stem & $\mathrm{kg}$ tree $^{-1}$ & 3.80 & 123.58 & 35.63 & 27.79 & 5.07 \\
\hline Bark & $\mathrm{kg}_{\text {tree }}{ }^{-1}$ & 0.38 & 9.35 & 3.91 & 2.07 & 0.38 \\
\hline Branch & $\mathrm{kg}$ tree $^{-1}$ & 0.16 & 23.59 & 2.37 & 4.33 & 0.79 \\
\hline Foliage & $\mathrm{kg}$ tree $^{-1}$ & 0.13 & 3.36 & 1.27 & 0.83 & 0.15 \\
\hline Total & $\mathrm{kg}_{\text {tree }}{ }^{-1}$ & 4.48 & 129.22 & 43.17 & 31.95 & 5.83 \\
\hline
\end{tabular}

Tabel 3 Relative contribution of every tree component namely stem, bark, branch, and foliage into total carbon storage in Eucalyptus urophylla at the surveyed area

\begin{tabular}{lrrrrr}
\hline \multirow{2}{*}{ Tree component } & \multicolumn{5}{c}{ Relative contribution to carbon storage (\%) } \\
\cline { 2 - 6 } & Min & Max & Mean & SD & SE \\
\hline Stem & 50.43 & 95.64 & 80.06 & 9.15 & 1.67 \\
Bark & 2.27 & 45.82 & 11.89 & 7.90 & 1.44 \\
Branch & 1.16 & 20.70 & 4.69 & 3.67 & 0.67 \\
Foliage & 0.93 & 9.16 & 3.36 & 1.66 & 0.30 \\
\hline
\end{tabular}

Tabel 4 Biomass distribution in every tree component (Mean SD) across the diameter classes of Eucalyptus urophylla

\begin{tabular}{|c|c|c|c|c|c|c|c|c|}
\hline \multirow{2}{*}{$\begin{array}{l}\text { Diameter } \\
\text { class }(\mathrm{cm})\end{array}$} & \multicolumn{2}{|c|}{ Stem/AGB } & \multicolumn{2}{|c|}{ Bark/AGB } & \multicolumn{2}{|c|}{ Branch/AGB } & \multicolumn{2}{|c|}{ Foliage/AGB } \\
\hline & Mean & SD & Mean & $\mathrm{SD}$ & Mean & SD & Mean & SD \\
\hline$<10$ & 71.17 & 13.91 & 19.93 & 13.77 & 4.59 & 2.42 & 4.31 & 3.00 \\
\hline $11-15$ & 82.12 & 7.91 & 11.42 & 5.59 & 3.61 & 2.33 & 2.85 & 1.13 \\
\hline $15-20$ & 82.70 & 4.50 & 8.93 & 2.25 & 5.09 & 5.05 & 3.28 & 1.18 \\
\hline $21-25$ & 81.59 & 9.94 & 10.26 & 5.92 & 4.90 & 3.01 & 3.25 & 1.20 \\
\hline$>26$ & 80.73 & 6.47 & 7.81 & 3.45 & 8.32 & 1.26 & 3.14 & 0.78 \\
\hline
\end{tabular}

Note: Data were presented in percentage

biomass E. urophylla was $\ln \hat{Y}=\ln a+b \cdot \ln D$. This models showed an accurate estimation up to $91.3 \%$. It verified the best selected model could explain the growth variation of $E$. urophylla in the study area, specifically related to total aboveground biomass. Our finding was relatively different with other previous studies about allometric models of $E$. urophylla in East Nusa Tenggara which conducted in natural forest (Marimpan, 2010; Almulqu et al., 2019).

This study also found there were similar pattern of biomass estimation using our best models with another model from the previous study of E. urophylla in natural forest at Mutis Timau, East Nusa Tenggara (Almulqu et al., 2019) (Figure 2). However, the value of estimated biomass from our model was considerably lower than allometric equations from Almulqu et al. (2019). It verified that our best model was only reliable to estimate aboveground biomass of E. urophylla in plantation forest while the model resulted by Almulqu et al. (2019) was only relevant to be used in natural forest of E. urophylla. This fact confirmed that the utilization of allometric equations for estimating tree biomass had limitations, such as type of forest, stand characteristics, management practice, and number of sample for destructive 
Table 5 Summary statistics of every allometric models for estimating aboveground biomass of E. urophylla plantation in East Nusa Tenggara

\begin{tabular}{|c|c|c|c|c|c|c|c|c|c|c|}
\hline $\begin{array}{c}\text { Response } \\
\text { variable }\end{array}$ & Equations** & $\operatorname{lna}$ & $\mathrm{b}$ & $\mathrm{c}$ & $\begin{array}{l}\mathrm{R}^{2} \\
\text { adj }\end{array}$ & RSE & RMSE & MAB & AIC & $\mathrm{CF}$ \\
\hline \multirow[t]{3}{*}{ AGB } & $\ln \hat{Y}=\ln a+b \cdot \ln D$ & $-0.751^{*}$ & $2.016^{*}$ & - & 0.913 & 0.517 & 0.499 & 0.353 & -1.323 & 1.132 \\
\hline & $\ln \hat{Y}=\ln a+b \cdot \ln \left(D^{2} H\right)$ & $5.211^{*}$ & $0.757^{\mathrm{ns}}$ & - & 0.946 & 0.500 & 0.483 & 0.337 & -1.387 & 1.123 \\
\hline & $\ln \hat{Y}=\ln a+b \cdot \ln D+c \cdot \ln H$ & $-5.182^{*}$ & $-0.534^{*}$ & $3.619^{\text {ns }}$ & 0.967 & 0.480 & 0.455 & 0.321 & -1.441 & 1.109 \\
\hline
\end{tabular}

Note: ** indicated that the $p$-value for all models was $<0.05$; "signified the $p$-value of fitted parameters was $<0.05$; ${ }^{\text {ns }}$ verified the $p$-value of fitted parameters was $>0.05$

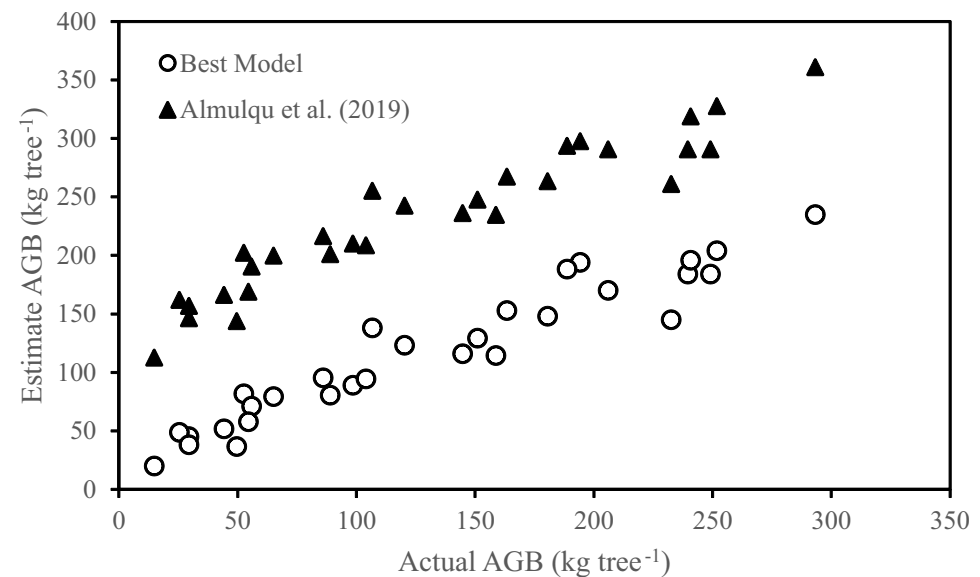

Figure 2 Comparison between the estimated total aboveground biomass using best model and other equations from previous studies at different site.

method (Altanzagas et al., 2019).

Referring to the results, our study realized the use of allometric models with single independent variable, $\ln \hat{Y}=\ln a+b \cdot \ln D$ had enough accuracy to estimate total aboveground biomass in E. urophylla. The additional of tree height as predictor variable in the equations provided more accurate estimation around $2-3 \%$, but the coefficient was not significant. Therefore, it would be better to use only diameter at breast height as predictor variable. In addition to its more simplicity, this parameter was relatively easier to be measured in forest inventory than tree height. Nevertheless, the allometric models constructed in this study had certain regional limitation since these models were developed based on the growth performance of E. urophylla stand in this site. Therefore, the model need further validation test to be used in the other regions, including other E. urophyhlla plantations.

\section{Conclusion}

The biomass distribution of E. urophylla in the surveyed area is highly varied in which most biomass were recorded in tree stem, followed by bark, branch, and foliage. The relative contribution of stem and bark to total aboveground biomass increased following the diameter class increment, while the dissimilar pattern was discovered in branch and foliage. The equation $\ln \hat{Y}=\ln a+b \cdot \ln D$ was reliable for estimating total aboveground biomass of E. urophylla. Those models provided good accuracy until $91.3 \%$ and had potential contribution to facilitating the more efficiency of forest inventory in E. urophylla plantations. We suggested to adopt these allometric equations for supporting sustainable eucalyptus plantation management at the study site.

\section{Acknowledgment}

Authors deliver our gratitude to Universitas Gadjah Mada for funding this research under the scenario of Penelitian Dasar Unggulan Peguruan Tinggi (PDUPT) with a contract agreement number 1711/UN1/ DITLIT/DIT-LIT/PT/2020. We also appreciate the reviewers' suggestions to this article. The appreciation is also addressed to the team of KPH Timor Tengah Selatan for facilitating the data collection process.

\section{References}

Almulqu, A. A., Arpornpong, N., \& Boonyanuphap, J. (2019). Biomass estimation and allometric equation for tree species in dry forest of East Nusa Tenggara, Indonesia. Forestry Ideas, 25(2), 369-384.

Altanzagas, B., Luo, Y., Altansukh, B., Dorjsuren, C., Fang, J., \& Hu, H. (2019). Allometric equations for estimating the above-ground biomass of five forest tree species in Khangai, Mongolia. Forests, 10(8), 1-17. https://doi.org/10.3390/f10080661

Arnhold, E. (2018). R-environment package for regression analysis. Pesquisa Agropecuaria Brasileira, 53(7), 870-873. https://doi.org/10.1590/S0100-204X2018 000700012

Daba, D. E., \& Soromessa, T. (2019). Allometric equations for aboveground biomass estimation of Diospyros abysinica (Hiern) F. White tree species. Ecosystem Health and Sustainability, 5(1), 86-97. https://doi.org/ 10.1080/20964129.2019.1591169 
Duncanson, L., Rourke, O., \& Dubayah, R. (2015). Small sample sizes yield biased allometric equations in temperate forests. Scientific Reports, 5, 1-13. https://doi.org/10.1038/srep17153

Ekoungoulou, R., Niu, S., Joël Loumeto, J., Averti Ifo, S., Enock Bocko, Y., Mikieleko, F., ..., \& Liu, X. (2015). Evaluating the carbon stock in above-and below- ground biomass in a moist Central African forest. Applied Ecology and Environmental Sciences, 3(2), 51-59. https://doi.org/10.12691/aees-3-2-4

Forrester, D. I., Tachauer, I. H. H., Annighoefer, P., Barbeito, I., Pretzsch, H., Ruiz-Peinado, R., ..., \& Sileshi, G. W. (2017). Generalized biomass and leaf area allometric equations for european tree species incorporating stand structure, tree age and climate. Forest Ecology and Management, 396, 160-175. https://doi.org/10.1016/ j.foreco.2017.04.011

Ghasemi, A., \& Zahediasl, S. (2012). Metabolism. International Journal of Endrocrinology Metabolism, 10(2), 486-489. https://doi.org/10.5812/ijem.3505

González-García, M., Hevia, A., Majada, J., \& Barrio-Anta, M. (2013). Above-ground biomass estimation at tree and stand level forshort rotation plantations of Eucalyptus nitens (Deane \& Maiden) Maiden in Northwest Spain. Biomass and Bioenergy, 54, 147-157. https://doi.org/ 10.1016/j.biombioe.2013.03.019

Goussanou, C. A., Guendehou, S., Assogbadjo, A. E., Kaire, M., Sinsin, B., \& Cuni-Sanchez, A. (2016). Specific and generic stem biomass and volume models of tree species in a West African tropical semi-deciduous forest. Silva Fennica, 50(2), 1-22. https://doi.org/10.14214/sf.1474

Guendehou, G. H. S., Lehtonen, A., Moudachirou, M., Mäkipää, R., \& Sinsin, B. (2012). Stem biomass and volume models of selected tropical tree species in West Africa. Southern Forests, 74(2), 77-88. https://doi.org/ $10.2989 / 20702620.2012 .701432$

Hakamada, R., Hubbard, R. M., Ferraz, S., \& Stape, J. L. (2017). Biomass production and potential water stress increase with planting density in four highly productive clonal Eucalyptus genotypes. Southern Forests: A Journal of Forest Science, 79(3), 251-257. https://doi.org/10.2989/20702620.2016.1256041

Han, S. H., \& Park, B. B. (2020). Comparison of allometric equation and destructive measurement of carbon storage of naturally regenerated understory in a Pinus rigida plantation in South Korea. Forests, 11(4), 1-11. https://doi.org/10.3390/F11040425

He, H., Zhang, C., Zhao, X., Fousseni, F., Wang, J., Dai, H., ..., \& Zuo, Q. (2018). Allometric biomass equations for 12 tree species in coniferous and broadleaved mixed forests, Northeastern China. PLoS ONE, 13(1), 1-16. https://doi.org/10.1371/journal.pone.0186226
Inail, M. A., Hardiyanto, E. B., \& Mendham, D. S. (2019). Growth responses of Eucalyptus pellita F . Muell plantations in South Sumatra to macronutrient fertilisers following several rotations of acacia. Forests, 10, 1-16. https://doi.org/10.3390/f10121054

Kalima, T., Malik, J., \& Sunarto. (2019). Eksplorasi jenis rotan di Kabupaten Timor Tengah Selatan, Provinsi Nusa Tenggara Timur. Journal Pro-Life, 6(2), 160-170. https://doi.org/10.33541/pro-life.v6i2

Kebede, B., \& Soromessa, T. (2018). Allometric equations for aboveground biomass estimation of Olea europaea L. subsp. cuspidata in Mana Angetu Forest. Ecosystem Health and Sustainability, 4(1), 1-12. https://doi.org/ 10.1080/20964129.2018.1433951

Kurniadi, R., \& Pujiono, E. (2009). Kandungan karbon di kawasan hutan Gunung Mutis. Kupang: Balai Penelitian Kehutanan Kupang.

Manuri, S., Brack, C., Noor'an, F., Rusolono, T., Anggraini, S. M., Dotzauer, H., \& Kumara, I. (2016). Improved allometric equations for tree aboveground biomass estimation in tropical dipterocarp forests of Kalimantan, Indonesia. Forest Ecosystems, 3(28), 1-10. https://doi.org/ 10.1186/s40663-016-0087-2

Marimpan, L. S. (2010). Inventore hutan alam jenis ampupu (Eucalyptus urophylla) dalam menghasilkan volume kayu batang, biomassa, dan karbon hutan (thesis). Yogyakarta: Universitas Gadjah Mada. Retrieved from https://repository.ugm.ac.id/id/eprint/85229

Mishra, P., Pandey, C. M., \& Singh, U. (2019). Descriptive statistics and normality tests for statistical data. Annals of Cardiac Anaesthesia, 22(1), 67-72. https://doi.org/ 10.4103/aca.ACA

Nugroho, N. P. (2014). Developing site-specific allometric equations for above-ground biomass estimation in peat swamp forests of Rokan Hilir District, Riau Province, Indonesia. Indonesian Journal of Forestry Research, 1(1), 47-65. https://doi.org/10.20886/ijfr.2014.1.1.4765

Nunes, L. J. R., Meireles, C. I. R., Gomes, C. J. P., \& Ribeiro, N. M. C. A. (2019). Forest management and climate change mitigation: A review on carbon cycle flow models for the sustainability of resources. Sustainability, 11(19), 1-10. https://doi.org/10.3390/su11195276

Pirralho, M., Flores, D., Sousa, V. B., Quilhó, T., Knapic, S., \& Pereira, H. (2014). Evaluation on paper making potential of nine Eucalyptus species based on wood anatomical features. Industrial Crops and Products, 54, 327-334. https://doi.org/10.1016/j.indcrop.2014.01.040

R Core Team. (2017). R: A language and environment for statistical computing. Retrieved from https://www.R-project.org/ 
Ribeiro, S. C., Soares, C. P. B., Fehrmann, L., Jacovine, L. A. G., \& von Gadow, K. (2015). Aboveground and belowground biomass and carbon estimates for clonal eucalyptus trees in Southeast Brazil. Revista Arvore, 39(2), 353-363. https://doi.org/10.1590/0100-67622015 000200015

Roxburgh, S. H., Paul, K. I., Clifford, D., England, J. R., \& Raison, R. J. (2015). Guidelines for constructing allometric models for the prediction of woody biomass: How many individuals to harvest? Ecosphere, 6(3), 1-28. https://doi.org/10.1890/ES14-00251.1

Sadono, R., Wardhana, W., Wirabuana, P. Y. A. P., \& Idris, F. (2020). Productivity evaluation of Eucalyptus urophylla plantation established in dryland ecosystems, East Nusa Tenggara. Journal of Degraded and Mining Lands Management, 8(1), 2461-2469. https://doi.org/ $10.15243 / \mathrm{jdmlm} .2020 .081 .2461$

Sanquetta, C. R., Dalla Corte, A. P., Pelissari, A. L., Tomé, M., Maas, G. C. B., \& Sanquetta, M. N. I. (2018). Dynamics of carbon and $\mathrm{CO}_{2}$ removals by Brazilian forest plantations during 19902016. Carbon Balance and Management, 13(1), 1-12. https://doi.org/10.1186/ s13021-018-0106-4

St-Onge, B., \& Grandin, S. (2019). Estimating the height and basal area at individual tree and plot levels in Canadian Subarctic Lichen Woodlands using stereo WorldView-3 images. Remote Sensing, 11(3), 248. https://doi.org/ $10.3390 /$ rs 11030248

Tesfaye, M. A., Gardi, O., Anbessa, T. B., \& Blaser, J. (2020). Aboveground biomass, growth and yield for some selected introduced tree species, namely Cupressus lusitanica, Eucalyptus saligna, and Pinus patula in Central Highlands of Ethiopia. Journal of Ecology and Environment, 44(1), 1-18. https://doi.org/10.1186/ s41610-019-0146-Z

Vega-Nieva, D. J., Valero, E., Picos, J., \& Jiménez, E. (2015).
Modeling the above and belowground biomass of planted and coppiced Eucalytpus globulus stands in NW Spain. Annals of Forest Science, 72(7), 967-980. https://doi.org/10.1007/s13595-015-0493-6

Viera, M., \& Rodríguez-Soalleiro, R. (2019). A complete assessment of carbon stocks in above and belowground biomass components of a hybrid eucalyptus plantation in Southern Brazil. Forests, 10(7), 536. https://doi.org/ 10.3390/f10070536

Wardhana, W., Widyatmanti, W., Soraya, E., Soeprijadi, D., Larasati, B., Umarhadi, D. A., ..., \& Wirabuana, P. Y. A. P. (2020). A hybrid approach of remote sensing for mapping vegetation biodiversity in a tropical rainforest. Biodiversitas, 21(9), 3946-3953. https://doi.org/ 10.13057/biodiv/d210904

Wirabuana, P. Y. A. P., Sadono, R., \& Jurniarso, S. (2019). Fertilization effects on early growth, aboveground biomass, carbon storage, and leaf characteristics of Eucalyptus pellita F.Muell. in South Sumatera. Jurnal Manajemen Hutan Tropika, 25(3), 154-163. https://doi.org/10.7226/jtfm.25.3.154

Wirabuana, P. Y. A. P., Setiahadi, R., Sadono, R., Lukito, M., Martono, D. S., \& Matatula, J. (2020). Allometric equations for estimating biomass of community forest tree species in Madiun, Indonesia. Biodiversitas, 21(9), 4291-4300. https://doi.org/10.13057/biodiv/d210947

Xue, Y., Yang, Z., Wang, X., Lin, Z., Li, D., \& Su, S. (2016). Tree biomass allocation and its model additivity for Casuarina equisetifolia in a tropical forest of Hainan Island, China. PLoS ONE, 11(3), 1-20. https://doi.org/10.1371/journal.pone.0151858

Zhao, H., Li, Z., Zhou, G., Qiu, Z., \& Wu, Z. (2019). Sitespecific allometric models for prediction of above-and belowground biomass of subtropical forests in Guangzhou, Southern China. Forests, 10(10), 1-16. https://doi.org/10.3390/f10100862 